\title{
Daňové úlevy pro zaměstnance podporující sportovní družstva dětí a mládeže
}

\section{Tax relief of employees supporting sports teams of children and young people}

\author{
Pavel Semerád ${ }^{1}$, Viktor Pruša ${ }^{2}$, Oldřich Racek ${ }^{2}$
}

${ }^{1}$ Provozně ekonomická fakulta Mendelovy univerzity, Brno

${ }^{2}$ Fakulta sportovních studií Masarykovy univerzity, Brno

\begin{abstract}
Abstrakt:
Článek má za cíl pomocí daně z př́jmů zvýšit př́ijmy do rozpočtů družstev dètí a mládeže. Úpravy v zažitých trendech by mohly přinést vy̌šsi zájem a podporu sportu v jeho okolí. Variabilita a kreativita je široká, a obecné řešení neexistuje. Jsou navrženy úpravy současné podpory ve formě peněžních a nepeněžních darů, a získávání peněz od zaměstnavatelù tak, aby byly využity ke snížení daňově povinnosti. Protože finanční zátěž přechází na rodiče, měla by být tato jejich činnost v rámci zákona zohledněna. Většina návrhư je uplatnitelná také v družstvech dospělých. Kluby by mohly získat modernizací své ćinnosti větší prestiž, atraktivitu a více peněz.
\end{abstract}

\begin{abstract}
:
The aim of this article is to increase incomes to the budgets of teams of children and young people by using income tax. The changes in the usual trend could also arouse greater interest in supporting neighbourhood sport. Variability and creativity are broad and a general solution does not exist. Changes to current support in the form of gifts in cash, gifts in kind and getting money from employers are proposed in such a way that they might be used to reduce tax liability. Because the financial burden is shifted to parents, the law should take their activity into account. Most of the proposals are also applicable to adult teams. By modernization of their activity the clubs could get higher prestige, higher attractiveness and larger amounts of money.
\end{abstract}

Klíčová slova: Nepeněžní dar, peněžní dar, podpora od zaměstnavatelu, podpora sportovních družstev Key words: $\quad$ Gifts in kind, gifts in cash, employer support, support of sports teams

Práce vznikla za finanční podpory projektu IGA č. 17/2012 Provozně ekonomické fakulty Mendelovy univerzity $v$ Brně.

\section{ÚVOD}

Sport a pohybová aktivita jsou nedílnou součástí lidského života a zvyšují pravděpodobnost úplnější komplexnosti procesu socializace a vyšší úrovně sociálních vazeb (Sekot, 2004). Sportovní činnosti patří do základních hodnot a potřeb lidí bez ohledu na to, v jaké době jsou provozovány (Sommer, 2003).

Sport, $\mathrm{v}$ souladu s hodnotovým zakotvením a směřováním soudobé postmoderní, na konzumaci mediálních představ a proměnlivost zážitků zaměřené společnosti, je stále výrazněji spojován s komerčním sponzorským logem na dresech atletů, s arénami, které jsou svědky významných sportovních událostí, a s mediálním zpravodajstvím, které je zprostředkovávají (Sekot, 2008).

Zatímco v minulosti byl sport financován rozdělováním státních příspěvků, dnes se musí oddíly a kluby starat o své př́ijmy především samy (Sekot et al., 2004). Sportovní mládežnické oddíly jsou čím dál častěji odkázány na finanční a materiální pomoc, bez které by nebyly schopny vykonávat svoji činnost. Tato okolnost je v podstatě problematická pro rozvoj sportu, pro část veřejnosti, zejména pro děti a mládež (Dovalil, 2002).

Na rozdíl od vrcholového „komerčního“ sportu mají mnohem složitější pozici družstva mládeže. Přestože největší vliv na aktivní provozování sportu mládeže mají demografické charakteristiky (věk a pohlaví), lze nezanedbatelný význam připsat i sociálnímu postavení (Sekot, 2008). Z tohoto důvodu jsou ve většině případů mládežnické kluby odkázány na pomoc obcí, rodičů a rodinných příslušníkủ, a dal- 
ších nadšenců obětujících vlastní volný čas pro jejich sportování. Je pochopitelné, že míra organizovanosti sportovní činnosti je v př́padě mládeže - a tím spíše dětí - velmi významná. Rodiny bez náležitého finančního zázemí, nezbytného pro tento druh sportovní zaměřenosti, mohou být zcela zjednodušeně hodnoceny jako nedostatečně pečující o svoji ratolest (Sekot, 2006). Přestože například výzkumné šetření (Čech, 2002) poukazuje na působení asi třiceti procent dětí v sportovních oddílech a tělovýchovných jednotách, stále existují rodiny, které si nemohou sportování svých dětí v těchto oddílech dovolit. Primárním důvodem je fakt, že na př́spěvky a základní sportovní vybavení nemají dostatečné finanční možnosti.

Sportovní trénink stejně jako spolupráce mezi klubem a rodinou je dlouhodobým programem všestranného rozvoje sportovce ve vybraném sportovním odvětví (Novotný, 2010). Mladí lidé si často prostřednictvím sportu tvoří a definují svoji identitu (Slepička, 2009). Považujeme jej tedy za jedinečný nástroj budování fyzického a duševního blahobytu, za platformu spoluutváření zdravého pocitu sounáležitosti v dané komunitě (Sekot, 2006).

Pro posílení vztahů mezi kluby a rodiči jsou pořádány informativní schůzky před začátkem (a v průběhu) sportovní sezony. Nejčastějším místem a časem pro možné společné setkání a poznání jsou sportovní utkání. Někteří rodiče ${ }^{1}$ se podílí na chodu klubu ve svém volném čase. Obvykle klub podporují téměř nebo zcela bez finančních nároků. Nabízí se otázka, jak ocenit jejich práci pro družstvo. Jednou z možností kompenzace by mohla být forma daru, a to bud'v peněžní nebo nepeněžní formě.

Zákon o dani z př́imů umožňuje rodičům získat finance pro klub od zaměstnavatele. Úskalí i výhody jsou vysvětleny v kapitole 5 .

\section{DAR}

Dar je předmětem daně darovací. Jedná se o bezúplatné nabytí majetku na základě právního úkonu, a to jinak než smrtí zůstavitele. Majetkem pro účely daně darovací mohou být nemovitosti a movitý majetek, př́p. jiný majetkový prospěch (Daňhelová, 2002) V praxi to znamená, že fyzická nebo právnická osoba převede nebo předá, bezúplatně a bez očekávání protihodnoty, dar jiné fyzické nebo právnické osobě. Aby bylo možné dar uplatnit pro daňové účely, je nezbytné mít tento převod podložen písemnou darovací smlouvou, ve které je vhodné uvést i účel využití daru. Dle daně darovací \$20 odst. 4 písm. a) je totiž osvobozeno od daně bezúplatné nabytí majetku na zabezpečení činnosti, pro kterou byla obdarovaná právnická osoba založena nebo zřízena. Mezi takové činnosti patří i tělovýchova a sport.

Z pohledu dárce jako fyzické osoby jsou dary nezdanitelnou částí základu daně \$15 odst. 1. daně z př́ijmů fyzických osob. Od základu daně lze odečíst hodnotu darů poskytnutých mj. na účely tělovýchovné a sportovní. Proto, aby byl dar daňovým darem, musí jeho úhrnná výše přesáhnout $2 \%$ ze základu daně ve zdaňovacím období (kalendářním roce), nebo musí činit alespoň 1000 Kč. Současně nesmí přesáhnout $10 \%$ základu daně. Dar se odečítá od základu daně, nikoliv od daně samotné. V České republice je sazba daně z př́ijmů fyzických osob $15 \%$. Z každé stokoruny si tak sníží dárce daň o 15 Kč a 85 Kč dá klubu ze svého. To by mohlo dárce odradit od podpory. V tomto článku jsou cílovou skupinu právě ti, kteří klub podporují různou formou již nyní.

\section{Příklad 1. Výpočet minimální a maximální výše daru}

Pan Novák je zaměstnán a jeho hrubá mzda je 10000 Kč měsičně. Jeho děti sportují v místním sportovním klubu. Pan Novák by chtěl podpořit jeho činnost. Neví však, jakou nejnižší a nejvy̌̌ší částku mưže klubu poskytnout, aby byl dar v maximálně možné daňové výši.

1 Pojmem rodič je pro účely článku myšlen kterýkoliv rodinný př́slušník, pečovatel o dítě, jakož i jiné osoby, které lze zařadit mezi přátele klubu. 
Dar je možné uplatnit až po konci zdaňovacího období, které je u fyzických osob kalendářní rok. Jestliže má pan Novák pouze př́jmy od jednoho zaměstnavatele, dle \$6 zákona o dani z př́ijmü2 může požádat o roční zúčtování daně svého zaměstnavatele. Ten provede roční zúčtování do 15. února. Jestliže má pan Novák více zaměstnavatelů současně anebo více druhů př́jmů (napřr. z pronájmu), je povinen podat sám daňové přiznání do 31 . března.

Výpočet základu daně se provede následovně:

Pan Novák je zaměstnán po celý kalendár̆ní rok, proto se provede součet (součin) hrubých mezd. $10000 \mathrm{~K} \check{c} \times 12=120000 \mathrm{~K} \check{c}$

Pro vypočet dílčího základu daně (DZD) dle $\$ 6$ se musí k hrubému př́jmu připočitat sociální (25\%) a zdravotní pojištěni (9\%) placené zaměstnavatelem. Veřejnosti je tato částka známá jako „superhrubá mzda“, ačkoliv tento pojem není nikde definován.

$D Z D_{s 6}=120000 \mathrm{Kc} \times 1,34=160800 \mathrm{~K} \check{c}$.

Pan Novák tak může sportovnímu klubu dát finanční dar nejméně 3216 Kč (2 \% ze základu daně) nebo 1000 Kč a maximálně ve výši 16080 Kč (10 \% ze základu daně). Podobně by se vypočítala výše daru, pokud by měl pan Novák další př́jmy.

\section{PENĚŽNÍ DARY}

Peněžní dary jsou častou formou podpory sportovních klubů. Může je totiž poskytnout úplně každý i bez jakýchkoliv znalostí o potřebách družstva. Výše peněžního daru závisí na dárci, pro daňové účely ale musí splňovat uvedené limity. Pokud by měl být dar ve vy̌šsí hodnotě, potom by bylo daňově výhodnější rozdělit dar na více osob, např. na oba rodiče. Pokud by např. pan Novák dal klubu dar 20000 Kč, daňový základ si bude moci snížit jen o 16080 Kč. Co udělat se zbývající částkou 3920 Kč? Má-li jeho manželka zdanitelné př́ímy, bylo by daňově výhodnější, aby tuto zbývající část uplatnila v ročním zúčtování (daňovém přiznání) ona.

Všichni hráči platí klubu př́íspěvky, které jsou určeny pro financování chodu klubu. Příspěvky stejně jako dary kluby danit nemusí, protože př́mo souvisí s činností, pro kterou byly zřízeny. Nabízí se proto otázka, jak tyto příspěvky daňově zvýhodnit. Mezi př́ijmy, které sice jsou předmětem daně, ale od daně jsou osvobozené, patří prŕíjmy z členských příspěvků přijatých zájmovými sdruženími právnických osob, občanskými sdruženími aj. dle $\$ 19$ odst. 1 písm. a) zákona o dani z přímů. Toto osvobození platí za podmínky, že se jedná o členské prŕíspěvky dle stanov, statutu, zřizovacích a zakladatelských listin přijaté neziskovou organizací, $v$ tomto prŕpadě sportovním oddílem. V opačném prŕpadě je nelze osvobodit.

Předmětem daně nejsou př́ijmy získané mj. darováním nemovitosti nebo movité věci dle $\$ 18$ odst. 2 písm. a) zákona o dani z př́ímů.

Občanské sdružení, v našem prrípadě sportovní klub, tak neplatí daň z př́ímů, ani z příspěvku, ani z daru. Daňové zvýhodnění má dárce pouze z daru. Nabízí se proto řešení, změnit zažitý trend placení př́spěvků. Necht̉ rodiče a hráči dávají klubům dary. To je zcela legální postup, jak může každá fyzická (i právnická) osoba optimalizovat svou daňovou povinnost.

\section{NEPENĚŽNÍ DARY}

Od základu daně lze odečíst také hodnotu nepeněžního daru. Pro stanovení jeho výše je nutné provést ocenění dle zákona č. 151/1997 Sb. o oceňování majetku. Př́íladem může být např. poskytnutí služby nebo movitá věc (vybavení, zboží, aj). V souvislosti s činností klubů lze uvést následující typy.

2 Př́ijmy ze závislé činnosti a funkčních požitků (pro zjednodušení „ze zaměstnání). 


\subsection{Cestovné}

Při cestování na utkání využívají kluby veřejné hromadné prostředky. Někteří rodiče vozí své děti (a spoluhráče) osobními vozidly nebo mikrobusy. Snaží se v rámci svých možností šetřit finanční prostředky klubům, chtějí trávit čas se svými dětmi a v neposlední řadě jsou hrdými fanoušky. Některá družstva cestovné rodičům proplácejí formou cestovního př́kazu automaticky, jiná dávají rodičům na výběr. Často se rodiče bud' ostýchají o cestovné přihlásit a vyúčtovat je, jiní je velkoryse odmítají. Nelze opomenout, že přepravou dětí ve vozidle přebírá řidič ( $v$ tomto prŕípadě rodič) zodpovědnost za jejich bezpečnost. Nelze se divit, pokud rodiče tuto službu odmítnou.

Tento př́pad je z daňového hlediska nepeněžním darem. Pokud tedy rodič odmítne cestovné, klub by mohl toto jednání ocenit a formou daru umožnit rodiči snížení daňové povinnosti. Jak ale vypočítat výši cestovní náhrady? Je možné postupovat dle vnitřní směrnice sportovního klubu, která stanoví, v jaké výši a rozsahu bude náhrady vyplácet (oceňovat). Náhrady lze vyplácet (ocenit) např. v souladu se zákoníkem práce, na který se může vnitřní směrnice odvolat.

\section{Př́íklad 2. Výpočet cestovních náhrad}

Pan Novák jede svým osobním vozidlem na sportovní utkání z Brna do Prahy (vzdálenost $420 \mathrm{~km}$ ). Na čerpací stanici natankoval 60 litrư motorové nafty za 34,80 Kč/litr. Průměrná spotřeba vozidla byla 6,20 litrů/100 km. Z Brna vyjel v sobotu v 8:00 a vrátil se v neděli v 12:00. Ubytování hradil klub.

Osobní automobil má průměrnou spotřebu vozidla uvedenou v technickém průkazu. Dalším údajem nezbytným pro výpočet cestovních náhrad je cena nakoupených pohonných hmot. Tu lze doložit bud'daňovým dokladem od čerpací stanice, nebo se použije výše průmèrné ceny za jeden litr pohonné hmoty podle $\$ 158$ zákoníku práce. Za každý ujetý kilometr náleži řidiči také základní cestovní náhrada ve výši 3,70 Kčl $k m^{\rrbracket}$.

Průmèrná cena $z a \mathrm{~km}=($ spotřeba vozu $\times$ cena pohonné hmoty $): 100+3,70$

Pan Novák dostane 5,85 Kč /km. Za celou cestu má nárok na $2457 \mathrm{Kč}$.

Každému na pracovní cestě náleží také stravné dle vyhlášky č. 429/2011 nejméně:

a) 64 Kč, trvá-li pracovní cesta 5 až 12 hodin,

b) 96 Kč, trvá-li pracovní cesta déle než 12 hodin, nejdéle však 18 hodin,

c) 151 Kč, trvá-li pracovní cesta déle než 18 hodin.

Pan Novák strávil na cestě $v$ sobotu 16 hodin a v neděli 12 hodin. Za první den mu náleží stravné ve výši 96 Ǩ̌ a za druhý 64 Ǩ́.

Celkové cestovní výlohy tak za tuto cestu na sportovní utkání byly 2617 Kč.

\subsection{Pomoc při tréninkových jednotkách}

Pomocní trenéři-dobrovolníci. Sportovní nadšenci z řad rodičů často pomáhají dle svých zkušeností trenérům s jejich prací. Nemusí se jednat jen o rodiče-amatéry. Často se na sportovištích objevují bývalí nebo aktivní sportovci různých sportovních odvětví a úrovní. Všichni se však snaží mladým sportovcům předat své rady a zkušenosti. Většina těchto dobrovolníků vykonává svoji činnost bez nároku na protihodnotu, vykonávají ji ve svém volném čase s obrovským úsilím. Nejsou výjimečné případy, kdy se z dobrovolníka stane trenér družstva po (nebo i bez) absolvování příslušného odborného školení. Jak ocenit jejich pomoc, která představuje skrytou finanční úsporu pro klub? Většina dobrovolníků tvrdí, že kdyby na sportovišti nebylo jejich dítě, asi by tuto činnost neprováděli. $Z$ tohoto je patrné, že se nejedná o samozřejmost. Vhodnou protihodnotou by mohla být forma nepeněžního daru.

Nejvhodnějším způsobem by byla cena obvyklá⿴囗 V klubech jsou trenéři odměňováni obvykle nějakou fixní (neměnnou) částkou za měsíc. Po vydělení částky počtem hodin na sportovišti nám vyjde hodinová sazba. Ta by mohla být přiznána i dobrovolníkům.

\section{Příklad 3. Ocenění práce pomocných trenérů}

Pan Novák pomáhá trenérovi družstva mládeže. Účastní se všech tréninků družstva; celkem 20 hod/měsičně. Trenér družstva dostává od klubu 5000 Kč měsičně za 32 hod/měsičně vč. zápasů. 
Dle výše uvedeného postupu je obvyklou hodinovou sazbou 156,25 Kč. Panu Novákovi by mohlo být formou nepeněžního daru přiznáno $3125 \mathrm{Kč} /$ měsičně. To je nejvyšší možná částka, která by měla být akceptována jako obvyklá cena. Ve výkonnosti jsou značné rozdíly, které by se mohly promítnout v částce daru.

\subsection{Další typy nepeněžních darů}

Někteří rodiče mohou nakoupit v průběhu sezony různé vybavení nebo výživové doplňky. Může se jednat o sportovní náčiní, které pomáhá ke zvyšování výkonnosti sportovců, nebo různé druhy občerstvení pro doplnění pitného režimu a energetických hodnot. Při př́ležitosti konce sezony organizují družstva závěrečné posezení s hráči a rodiči. Často se i na těchto posezeních finančně nebo materiálně podílejí rodiče.

Jako další prríklady lze uvést vedení účetnictví, vyřizování organizačních povinností, překlad a tlumočení na zahraničních zápasech, tvorba webových stránek pro propagaci klubu na internetu aj. Jestliže nedojde k protihodnotě, mohly by být tyto činnosti uznány jako dar.

\section{Př́íklad 4. Darování sportovního náčiní a pomůcek}

Pan Novák koupil 4 ks míčù, které daroval sportovnímu klubu. Zaplatil za ně dohromady 2000 Kč. Protože je známa výše pořizovacích nákladư, bude tento nepeněžní dar oceněn pořizovacími náklady ${ }^{3}$ v tomto př́padě $2000 \mathrm{Kc}$.

\section{Př́íklad 5. Tvorba webových stránek}

Pan Novák vytvoři bez nároku na odměnu webové stránky družstva. Kdyby si nechal klub vytvořit tyto stránky od odborné firmy, zaplatil by za ně 8000 Kč. Finanční úspora, která klubu vznikne, mủže být označena jako dar v této výši. Bylo by vhodné, aby si klub zjistil předem alespoň jednu cenovou nabídku od specializované firmy. Ziská tak podklad pro správce daně, že ocenil službu správně.

\section{PROKAZATELNOST POSKYTNUTÉHO DARU}

Dárce, fyzická osoba, která chce dar uplatnit jako nezdanitelnou část základu daně, musí tuto skutečnost správci daně prokázat. Měl by mít potvrzení od obdarovaného. Není stanovena žádná závazná forma takovéhoto dokladu (potvrzení). Nejprůkaznějším prostředkem je písemná smlouva uzavřená dle $\$ 628-630$ občanského zákoníku. Ze smlouvy by mělo být zřejmé:

- kdo je dárcem,

- kdo je obdarovaný,

- účel poskytnutí daru,

- hodnota daru v peněžní jednotce,

- datum poskytnutí daru,

- potvrzení o převzetí daru, pokud není dar předán v den podpisu smlouvy.

Smlouva může být nahrazena také př́ímovým pokladním dokladem. I zde by měly být zř̌etelně uvedeny náležitosti jako u darovací smlouvy. Potvrzení (tuto smlouvu) předá poplatník (dárce) svému zaměstnavateli k ročnímu zúčtování, nebo ji přiloží k daňovému přiznání.

\section{Př́íklad 6 Vzor darovací smlouvy}

Darovací smlouva

3 Aktuální částka pro rok 2011 i 2012 je nejméně 3,70 Kč/km dle vyhlášky 429/2011 Sb., o změně sazby základní náhrady za používání silničních motorových vozidel a stravného a o stanovení průměrné ceny pohonných hmot pro účely poskytování cestovních náhrad. 
uzavřena v souladu s ustanovením $\$ 628$ a následujících ustanovení zákona č.40/1964 Sb. občanského zákoníku ve znèní pozdějšich predpisù.

Smluvní strany:

Jméno a príimení

Datum a místo narození / Rodné číslo

Trvalé bydliště

(dále jen „dárce"),

$a$

Název sportovního oddílu

Identifikační čislo

Sídlo

Zastoupen (Smlouvu musí podepsat statutární zástupce nebo jiná osoba, která má oprávnèní jednat za klub napřr. na základě plné moci. V opačném př́padě by byla smlouva neplatná.)

(dále jen „obdarovaný"),

uzavíraji na základě vzájemné shody tuto darovací smlouvu.

Předmèt smlouvy

Předmětem této smlouvy je dar (je možné specifikovat i materiální dar, ale musí být vyčíslen v peněžních jednotkách) v celkové hodnotè -Ǩ́.

Dar poskytuje dárce obdarovanému dobrovolně ( $k$ využití ve prospěch/ pro účel) ......... S darem dárce nespojuje žádnou protislužbu ze strany obdarovaného.

Obdarovaný potvrzuje, že dar prevzal/převezme (ke dni podpisu smlouvy/př́padně lze stanovit jiné datum).

Tato smlouva se vyhotovuje ve 2 stejnopisech, z nichž po 1 obdrží každá ze smluvních stran.

Obě strany prohlašují, že darovací smlouvu sepsaly na základě svobodné vưle, smlouvu si přečetly a sejím obsahem souhlasí. Toto potvrzují svými podpisy.

V dne

podpis dárce

podpis obdarovaného

\section{PODPORA SPORTOVNÍCH AKTIVIT ZAMĚSTANAVATELI}

$\mathrm{V}$ úvodu již bylo zmíněno, že si někteří rodiče nemohou dovolit sportování svých dětí z finančních důvodů. Pro rodiče může být velice obtížné vysvětlit dítěti, že nemůže jít s kamarády na hřiště, protože na to prostě není v rodinném rozpočtu dost financí. I tady existuje několik variant, jak to dítěti umožnit.

Kluby mohou část nebo celou výši př́spěvků (nebo i jiných nákladů) svému členovi odpustit. Postup se užívá především u talentovaných jedinců, u kterých lze předpokládat vysoká sportovní výkonnost a přínos pro klub v dalších letech.

Zákon o dani z příjmů umožňuje daňovou možnost financování zaměstnanců a jejich rodinných př́islušníků ve formě možnosti používat rekreační, zdravotnická a vzdělávací zařízení, předškolní zařízení, závodní knihovny, tělovýchovná a sportovní zařízení nebo ve formě prŕíspěvku na kulturní pořady a sportovní akce. Rodič může požádat svého zaměstnavatele, aby za něj uhradil sumu za sportování dítěte $\mathrm{v}$ klubu. Plnění může jít $\mathrm{z}$ fondu kulturních a sociálních potřeb, ze sociálního fondu, ze zisku (př́jmů) po jeho zdanění. Zjednodušeně řečeno, jestliže se jedná o zaměstnavatele, který dosáhl zisku a ten zda- 
nil, může zaměstnanci poskytnout toto nepeněžní plnění. Je jen na vůli zaměstnavatele, zda plnění poskytne. Výjimkou by mohly být velké organizace, kde fungují odbory a kde je toto řešení vyjednáno v kolektivní smlouvě. Vzhledem k finanční krizi však mnoho společností nakládá s penězi opatrně, a raději je investují do vlastní činnosti. Pro zaměstnance je tento př́ijem nedaňový.

Pokud by se sám zaměstnavatel (právnická osoba) rozhodl k poskytnutí daru, limity jsou alespoň 2000 Kč a maximálně $5 \%$ ze základu daně (\$20 odst. 8 zákona o daních z př́jmů).

Další možností je poskytnutí plnění zaměstnavatelem na vrub výdajů zaměstnavatele, které však nejsou výdaji na dosažení, zajištění a udržení př́ijmů. Stejně jako předchozí možnost závisí vše na vůli zaměstnavatele.

Pro zaměstnavatele je výhodnější (možná i zajímavější), když takový výdaj je daňově uznatelný dle $\$ 24$ zákona o dani z př́imu ${ }^{4}$. Za takový výdaj lze považovat např. reklamu. Sportovní klub se ve smlouvě o reklamě zaváže k určité formě propagace. Tím, že získá protihodnotu, může být ochotnější k finanční podpoře. Pro klub je však takové plnění př̀edmětem daně z př́ijmů. Pokud rodič touto formou zajistí finance, měl by být, dle názoru autorů tohoto článků, klubem osvobozen od placení př́spěvků za sportování dítěte.

\section{ZÁVĚR}

V dnešní době je velice obtížné získat zájem podnikatelských subjektů (at již fyzických nebo právnických osob), které by byly ochotny podporovat činnost jakékoliv neziskové organizace. Tyto subjekty mají mnoho práce s udržením svého postavení na trhu a podporu at už finanční nebo materiální považují za př́těž.

Tlak na zajištění financí tak přechází z větší části na samotné sportovce a kluby bez ohledu na výkonnostní úroveň a druh sportu. Náš článek se zabývá možnostmi daňového zvýhodnění fyzických osob, které podporují různými zpo̊soby chod sportovního klubu. Jsou vymezeny různé druhy činností, se kterými se setkáváme při jeho fungování. Často nejsou nijak ohodnoceny, a to i pro neznalost daňových zákonů; v horším př́ípadě se pomoc považuje za samozřejmost.

Při dodržení uvedených postupů může dojít k oboustrannému utužení vztahu mezi sportovním klubem a jeho podporovatelem, jako výsledku vzájemně výhodné spolupráce. I když např. úspěch ve sportovním utkání nelze převádět na peníze, při jejich nedostatku je jeho dosažení velice obtížné a někdy nemožné.

\section{LITERATURA}

ČECH, T. Volnočasové aktivity dětí mladšího školního věku počátku 21. století. In: Volný čas a jeho současné problémy. Olomouc: Hanex, 2002. s. 96 - 101

DAŇHELOVÁ, Š. Vybrané kapitoly z ekonomiky. Brno: Paido, 2002. 83 s. ISBN 80-7315-032-8

DOVALIL, J. a kol. Výkon a trénink ve sportu. Praha: Olympia, 2002. 336 s. ISBN

80-7033-760-5

NOVOTNÝ, J. a kol. Ekonomika sportu: vybrané kapitoly III. 1.vyd. Praha: Oeconomica, 2010. 194 s. ISBN 978-80245-1713-1

SEKOT, A. Sociologické problémy sportu. 1. vyd. Praha : GRADA Publishing, 2008. 224 s. ISBN 978-80-247-2562-8

SEKOT, A. Sociologie sportu. 1. vyd. Brno : Masarykova univerzita a Paido, 2006. 412 s. Pedagogická edice. ISBN 80-210-4201-X.

SEKOT, A., LEŠKA, D., OBORNÝ, D., JU゚VA. Sociální dimenze sportu. 1. vyd. Brno : Masarykova univerzita, 2004. 245 s. ISBN 80-210-3581-1

4 Výdaje (náklady) vynaložené na dosažení, zajištění a udržení přímmů. 
SEKOT, A. - BLAHUTKOVÁ, M. - DVOŘÁKOVÁ, Š. - SEBERA, M. Kapitoly ze sportu. Brno : Masarykova univerzita v Brně, 2004. 200 s. ISBN 80-210-3531-5

SLEPIČKA, P. - HOŠEK, V.- HÁTLOVÁ, B. Psychologie sportu. 2. vyd. Praha: Karolinum, 2011. 242 str. ISBN 978-80-246-1602-5

SOMMER, J. Malé dějiny sportu aneb o sportech našich předků. Fontána, 2003. 273 s. ISBN 80-7336-116-7 Vyhláška č. 429/2011 Sb., o změně sazby základní náhrady za používání silničních motorových vozidel a stravného a o stanovení průměrné ceny pohonných hmot pro účely poskytování cestovních náhrad Zákon č. 40/1964 Sb., občanský zákoník, ve znění pozdějších předpisů Zákon č. 151/1997 Sb., o oceňování majetku, ve znění pozdějších předpisů Zákon č. 262/2006 Sb., zákoník práce, ve znění pozdějších předpisů

Zákon č. 357/1992 Sb., o dani dědické, dani darovací a dani z převodu nemovitosti, ve znění pozdèjších předpisů

Zákon č. 586/1992 Sb., o daních z př́imů, ve znění pozdějších předpisů 